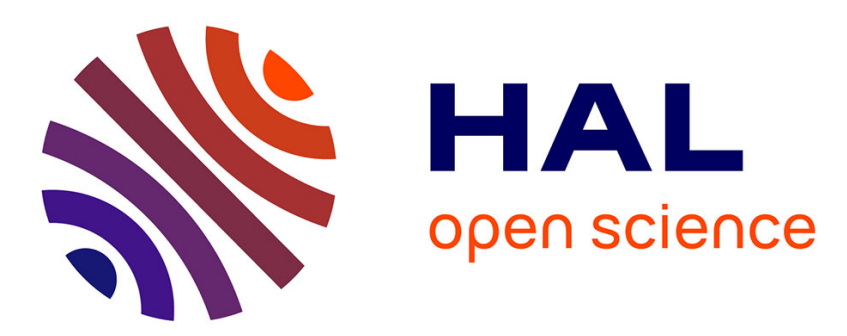

\title{
Governance and Migration in a South-North Partnership Thierry Baudassé
}

\section{To cite this version:}

Thierry Baudassé. Governance and Migration in a South-North Partnership. 2006. halshs-00010296

\section{HAL Id: halshs-00010296 \\ https://shs.hal.science/halshs-00010296}

Preprint submitted on 19 Apr 2006

HAL is a multi-disciplinary open access archive for the deposit and dissemination of scientific research documents, whether they are published or not. The documents may come from teaching and research institutions in France or abroad, or from public or private research centers.
L'archive ouverte pluridisciplinaire HAL, est destinée au dépôt et à la diffusion de documents scientifiques de niveau recherche, publiés ou non, émanant des établissements d'enseignement et de recherche français ou étrangers, des laboratoires publics ou privés. 


\title{
Governance and Migration in a South-North Partnership: the Teaching of Economic Analysis ${ }^{1}$
}

\author{
Thierry Baudassé - LEO, University of Orleans (France)
}

Summary: The aim of this paper is to study the relation between governance and migration in the case of a South-North partnership, using the tools of economic analysis. We will analyse both the governance of migratory phenomenon (i.e. the control of South-North migration, as much as the control of rural-urban or internal migration) and the consequences of internal and/or international migrations on a broader problem which is the compatibility of economic liberalization, political stability and other objectives which are pursued by governments (such as avoiding the deterioration of social capital, or a social dumping). In a first section we develop an original Harris-Todaro model in order to resolve the question of the compatibility of different policies. In a second section we will consider four possibilities to enrich the Harris-Todaro model, which are to take into account the cost of migration, the attitude toward risk, the relative deprivation hypothesis, and the relation between migration and social capital. In each case, our attention will be focused on the policy recommendations we can formulate as a result of every approach.

Key Words: rural-urban migration, international migration, agricultural liberalization, social capital.

JEL Codes: F 13, F 22, Q 17, Z 13

\footnotetext{
1 This research is a part of a European research contract $n^{\circ} 028386$ named « The Political Economy of Governance in the Euro-Mediterranean Partnership » (Go-EuroMed).
} 
The aim of this paper is to study the relation between governance and migration in the case of a South-North partnership, using the tools of economic analysis. We will analyse both the governance of migratory phenomenon (i.e. the control of South-North migration, as much as the control of rural-urban or internal migration) and the consequences of internal and/or international migrations on a broader problem which is the compatibility of economic liberalization, political stability and other objectives which are pursued by governments (such as avoiding the deterioration of social capital, or a social dumping). So, the field of our research is not only the governance of migration, but also the constraints that migration is setting in the economic and political governance. In order to attain our objective, we will use a Harris-Todaro-Fields model in section 1 and we will complete this approach in section 2. In the model of section 1, the main reason for migration is to equalize the expected income between sectors. This model leads to an original statement about the compatibility of various policies in an economy where Harris-Todaro type migration takes place. In the second section we will consider four possibilities to enrich the Harris-Todaro model, which are to take into account the cost of migration, the attitude toward risk, the relative deprivation hypothesis, and the relation between migration and social capital. In each case, our attention will be focused on the policy recommendations we can formulate as a result of every approach. In section 3 we present a table which summarizes our main results.

\section{1 - The lessons of a Harris-Todaro model}

In this section, we will use a simple Harris-Todaro model in order to demonstrate the incompatibility of various objectives such as agricultural liberalization, social clause, the control of south-north migration, political stability and budgetary equilibrium. In the first section we define the model, then in the second section we analyze the effects of several policies and in the third section we focus on the practical lessons of the model.

\section{1-1 : The model}

The model represents an economy producing two goods, one manufactured good and one agricultural good. The manufactured good can be produced in the formal sector or in the informal sector. The formal sector uses a fix amount of capital and pay taxes. Besides, the formal sector is constrained by a real minimum wage. The informal sector is composed of small individual producers who share equally the real amount of activity of the sector. The entrepreneurs in the informal sector don't pay taxes, but they sell their product at the same

price as the formal sector. The agricultural good is produced in the rural sector, which uses a fix amount of capital, pay taxes but which is not constrained by the minimum wage, following the tradition of Harris-Todaro models.

The individuals are perfectly mobile between the three sectors, and they have also the possibility of emigrate without any costs and work in the foreign informal sector (we suppose here that all the emigration is illegal, so that the migrants will necessarily work in the informal sector abroad). The foreign informal sector is supposed to have a fix real size, which is 
determined exogenously. As a consequence of these assumptions, the individuals have the choice between four situations:

- To work in the rural sector;

- To search a job in the (urban) formal sector, without any other activity than the search;

- To work part-time in the informal sector and search at the same time a formal job;

- To emigrate and work in the informal sector abroad.

The fundamental hypothesis is that the individuals are going to migrate between the four sectors until the equalization of expected income of the four sectors (rural, national formal, national informal and foreign informal). We suppose the individuals are risk-neutrals and we focus on the no-migration equilibria, i.e. the equilibria where the expected income is the same in all sectors.

We then use the following notations:

$\mathrm{w}_{\mathrm{a}}$ : real wage in the agricultural sector.

$\mathrm{w}_{\mathrm{u}}$ : real wage (fixed institutionally) in the urban sector. In fact, $\mathrm{w}_{\mathrm{u}}$ is the real minimum wage. It is supposed that the real minimum wage is higher than the wage that equilibrates the formal urban labour market, so that there is urban unemployment.

$\mathrm{Q}_{\mathrm{i}}$ : real size of the national informal sector

$\mathrm{Q}_{\mathrm{e}}$ : real size of the foreign informal sector

$\mathrm{q}$ : probability to find a formal job for an individual while seeking full-time. For an individual working in the informal sector and searching a formal job at the same time, this probability is h.q, with h<1 (see Fields).

$\mathrm{L}_{\mathrm{j}}$, with $\mathrm{j}=\mathrm{a}$, $\mathrm{i}$, e: population working respectively in the agricultural sector, informal national sector and foreign informal sector.

$\mathrm{L}_{\mathrm{u}}$ : individuals seeking full-time an urban formal work or having such a work

$\mathrm{E}_{\mathrm{u}}$ : individuals working in the urban formal sector, $\mathrm{L}_{\mathrm{u}}-\mathrm{E}_{\mathrm{u}}$ represents the unemployed population

L: total population

$P$ : general price level

$\mathrm{p}_{\mathrm{u}}{ }^{\mathrm{p}}$ and $\mathrm{p}_{\mathrm{a}}{ }^{\mathrm{p}}$ are the producer prices of the manufactured good and agricultural good

$\mathrm{p}_{\mathrm{u}}{ }^{\mathrm{c}}$ and $\mathrm{p}_{\mathrm{a}}{ }^{\mathrm{c}}$ are the consumer prices of the manufactured good and agricultural good

$\mathrm{p}_{\mathrm{u}}{ }^{\mathrm{m}}$ and $\mathrm{p}_{\mathrm{a}}{ }^{\mathrm{m}}$ are the world prices of the manufactured good and agricultural good

$\alpha$ is the part of agricultural products in the consumption basket

$t_{a}$ and $t_{u}$ are the sales taxes on the agricultural good and the manufactured good (only in the formal sector), $\mathrm{d}_{\mathrm{a}}$ is the customs duty for the agricultural good. It is supposed that the customs duty is nil for the manufactured good.

The following equations define the model equilibrium:

$$
\begin{aligned}
& \mathrm{w}_{\mathrm{a}}=\mathrm{P}_{\mathrm{a}} \cdot \mathrm{f}^{\prime}\left(\mathrm{L}_{\mathrm{a}}\right) \\
& \mathrm{w}_{\mathrm{a}}=\mathrm{q} \cdot \mathrm{w}_{\mathrm{u}} \\
& \mathrm{w}_{\mathrm{a}}=\mathrm{h} \cdot \mathrm{q} \cdot \mathrm{w}_{\mathrm{u}}+(1-\mathrm{hq}) \cdot \mathrm{Q}_{\mathrm{i}} / \mathrm{L}_{\mathrm{i}} \cdot \\
& \mathrm{w}_{\mathrm{a}}=\mathrm{Q}_{\mathrm{e}} / \mathrm{L}_{\mathrm{e}} \\
& \mathrm{w}_{\mathrm{u}}=\mathrm{P}_{\mathrm{u}} \cdot \mathrm{g}^{\prime}\left(\mathrm{E}_{\mathrm{u}}\right)
\end{aligned}
$$

\footnotetext{
${ }^{2}$ we suppose f' $>0$ and $\mathrm{f}^{\prime} '<0$

${ }^{3}$ we suppose g' $>0$ and g'' $<0$
} 


$$
\begin{aligned}
& \mathrm{q}=\mathrm{E}_{\mathrm{u}} /\left(\mathrm{L}_{\mathrm{u}}+\mathrm{L}_{\mathrm{i}} \cdot \mathrm{h}\right) \\
& \mathrm{L}_{\mathrm{a}}+\mathrm{L}_{\mathrm{i}}+\mathrm{L}_{\mathrm{u}}+\mathrm{L}_{\mathrm{e}}=\mathrm{L} \\
& \mathrm{P}_{\mathrm{a}}=\mathrm{p}_{\mathrm{a}}{ }^{\mathrm{p}} / \mathrm{P} \\
& \mathrm{P}_{\mathrm{u}}=\mathrm{p}_{\mathrm{u}}{ }^{\mathrm{p}} / \mathrm{P} \\
& \mathrm{P}=\alpha \cdot \mathrm{p}_{\mathrm{a}}{ }^{\mathrm{c}}+(1-\alpha) \cdot \mathrm{p}_{\mathrm{u}}{ }^{\mathrm{c}} \\
& \mathrm{p}_{\mathrm{a}}{ }^{\mathrm{c}}=\left(1+\mathrm{t}_{\mathrm{a}}\right) \cdot \mathrm{p}_{\mathrm{a}}{ }^{\mathrm{p}} \\
& \mathrm{p}_{\mathrm{u}}{ }^{\mathrm{c}}=\left(1+\mathrm{t}_{\mathrm{u}}\right) \cdot \mathrm{p}_{\mathrm{u}}{ }^{\mathrm{p}} \\
& \mathrm{p}_{\mathrm{a}}{ }^{\mathrm{c}}=\left(1+\mathrm{t}_{\mathrm{a}}\right) \cdot\left(1+\mathrm{d}_{\mathrm{a}}\right) \cdot \mathrm{p}_{\mathrm{a}}{ }^{\mathrm{m}} \\
& \mathrm{p}_{\mathrm{u}}{ }^{\mathrm{c}}=\left(1+\mathrm{t}_{\mathrm{u}}\right) \cdot \mathrm{p}_{\mathrm{u}}{ }^{\mathrm{m}} \\
& \mathrm{Q}_{\mathrm{i}}=\mathrm{a} \cdot \mathrm{t}_{\mathrm{u}}+\mathrm{b}
\end{aligned}
$$

Are exogenous: the functions $\mathrm{f}$ and $\mathrm{g}$, the variables $\mathrm{w}_{\mathrm{u}}, \mathrm{h}, \mathrm{Q}_{\mathrm{e}}, \mathrm{L}, \alpha, \mathrm{p}_{\mathrm{a}}{ }^{\mathrm{m}}, \mathrm{p}_{\mathrm{u}}{ }^{\mathrm{m}}, \mathrm{t}_{\mathrm{a}}, \mathrm{d}_{\mathrm{a}}, \mathrm{t}_{\mathrm{u}}, \mathrm{a}$ and $\mathrm{b}$. Are endogenous: $\mathrm{L}_{\mathrm{a}}, \mathrm{L}_{\mathrm{i}}, \mathrm{L}_{\mathrm{u}}, \mathrm{L}_{\mathrm{e}}, \mathrm{E}_{\mathrm{u}}, \mathrm{q}, \mathrm{w}_{\mathrm{a}}, \mathrm{P}, \mathrm{P}_{\mathrm{a}}, \mathrm{P}_{\mathrm{u}}, \mathrm{Q}_{\mathrm{i}}, \mathrm{p}_{\mathrm{a}}{ }^{\mathrm{p}}, \mathrm{p}_{\mathrm{a}}{ }^{\mathrm{c}}, \mathrm{p}_{\mathrm{u}}{ }^{\mathrm{p}}, \mathrm{p}_{\mathrm{u}}{ }^{\mathrm{c}}$ so that there is 15 endogenous variables.

Equations 1 and 5 result from the equality between nominal wage and the value of the marginal product in agricultural and manufactured formal sector. Equations 2 to 4 mean that in equilibrium expected income is identical in all sectors. There are two populations looking for a formal work: one population, which size is $\mathrm{L}_{\mathrm{u}}$, has a probability $\mathrm{q}$ of finding it and the other one, which size is $\mathrm{L}_{\mathrm{i}}$, has a probability h.q. The mean probability for the two populations is $\mathrm{E}_{\mathrm{u}} /\left(\mathrm{L}_{\mathrm{u}}+\mathrm{L}_{\mathrm{i}}\right)$, so that we can deduce of the total probability formula the equation 6. Equations 7 to 14 are accounting identities or definitions. Equation 15 means that the size of national informal sector is a linear function of $t_{u}$, which is the tax on manufactured good. Note that "a" can be positive or negative, which means that a rise in $t_{u}$ can have a positive or a negative effect on $\mathrm{Q}_{\mathrm{i}}$. $\mathrm{Q}_{\mathrm{i}}$ can also have an exogenous expansion, by changing the value of parameter $\ll \mathrm{b} »$.

It can be proved that:

(2) and (3) imply:

$$
L_{i}=\frac{Q_{i}}{(1-h) \cdot w_{a}}-\frac{Q_{i} \cdot h}{(1-h) \cdot w_{u}}
$$

From (2), (6) and (16) we deduce:

$$
L_{u}=\frac{(1-\mathrm{h}) \cdot \mathrm{E}_{\mathrm{u}} w_{u}-h \cdot Q_{i}}{(1-h) \cdot w_{a}}+\frac{h^{2} \cdot Q_{i}}{(1-h) \cdot w_{u}}
$$

(4), (7), (16) and (17) imply:

$$
\mathrm{L}_{\mathrm{a}}+\left[\mathrm{E}_{\mathrm{u}} \cdot \mathrm{w}_{\mathrm{u}}+\mathrm{Q}_{\mathrm{i}}+\mathrm{Q}_{\mathrm{e}}\right] /\left[\mathrm{P}_{\mathrm{a}} \cdot \mathrm{f}^{\prime}\left(\mathrm{L}_{\mathrm{a}}\right)\right]=\left[\mathrm{L}+\mathrm{h} \cdot \mathrm{Q}_{\mathrm{i}} / \mathrm{w}_{\mathrm{u}}\right]
$$

That is, if we note $\mathrm{C}$ the expression $\left[\mathrm{E}_{\mathrm{u}} \cdot \mathrm{w}_{\mathrm{u}}+\mathrm{Q}_{\mathrm{i}}+\mathrm{Q}_{\mathrm{e}}\right]$ and $\mathrm{D}$ the expression $\left[\mathrm{L}+\mathrm{h} \cdot \mathrm{Q}_{\mathrm{i}} / \mathrm{w}_{\mathrm{u}}\right]$ : $\mathrm{L}_{\mathrm{a}}+\mathrm{C} /\left[\mathrm{P}_{\mathrm{a}} \cdot \mathrm{f}^{\prime}\left(\mathrm{L}_{\mathrm{a}}\right)\right]=\mathrm{D}$ or :

$C / P_{a}-F \cdot f^{\prime}\left(L_{a}\right)=0$ with $F \equiv\left(D-L_{a}\right)$ 
It can be demonstrated that, in order to have $\mathrm{L}_{\mathrm{u}}>\mathrm{E}_{\mathrm{u}}$ (which means that there is some people unemployed) it is necessary and sufficient to have:

$E_{u} \cdot w_{u}>\frac{h}{(1-h)} \cdot \frac{(1-h q)}{(1-q)} \cdot Q_{i}$

We will now analyse the case of an economy which liberalizes its agriculture. In this model, national agriculture is protected by a customs duty $\mathrm{d}_{\mathrm{a}}$ and so national rural sector is having the advantage of a producer price above the world price for the agricultural good. As a result, the labour force in the rural sector is important. So, when the liberalization takes place, the labour force will go from the countryside to the cities. But, from another point of view, the customs duty is a source of income for the government and so, in order to maintain fiscal equilibrium, it is necessary to raise the sales taxes. Thus, it is also necessary to study the consequences of a raise in taxes in order to analyse the effects of agricultural liberalization.

\section{1 - 2: The Policies and their consequences}

In this model, the main origin of migration process is the liberalization of agricultural sector, and, as long as fiscal equilibrium is an objective for the government, this liberalization may be accompanied by a raise in taxes to compensate the shortage of fiscal resource. So we will study in this section the effects of a decrease in $d_{a}$ and the effects of an increase in $t_{a}$ and/or $t_{u}$. Our attention will be concentrated on the migratory consequences and we will study the compatibility of this liberalization policy with others objectives that a government may have.

\section{1-21: Consequences of a decrease in $d_{a}$}

It is possible to demonstrate the following result:

$\mathrm{dE}_{\mathrm{u}} / \mathrm{dd}_{\mathrm{a}}=\left(\mathrm{dE}_{\mathrm{u}} / \mathrm{dP}\right) \cdot\left(\mathrm{dP} / \mathrm{dp}_{\mathrm{a}}{ }^{\mathrm{c}}\right) \cdot\left(\mathrm{dp}_{\mathrm{a}}{ }^{\mathrm{c}} / \mathrm{dd}_{\mathrm{a}}\right)$ so that:

$\mathrm{E}_{\mathrm{u}}{ }^{\prime}\left(\mathrm{d}_{\mathrm{a}}\right)=\left[\alpha \cdot \mathrm{w}_{\mathrm{u}} \cdot \mathrm{p}_{\mathrm{a}}{ }^{\mathrm{m}} \cdot\left(1+\mathrm{t}_{\mathrm{a}}\right)\right] /\left[\mathrm{p}_{\mathrm{u}}{ }^{\mathrm{p}} \cdot \mathrm{g}^{\prime}{ }^{\prime}\left(\mathrm{E}_{\mathrm{u}}\right)\right]<0$.

$\mathrm{dP}_{\mathrm{a}} / \mathrm{dd}_{\mathrm{a}}=\left(\mathrm{dP}_{\mathrm{a}} / \mathrm{dp}_{\mathrm{a}}{ }^{\mathrm{p}}\right) \cdot\left(\mathrm{dp}_{\mathrm{a}}{ }^{\mathrm{p}} / \mathrm{dd}_{\mathrm{a}}\right)$, so:

$\mathrm{dP}_{\mathrm{a}} / \mathrm{dd}_{\mathrm{a}}=\left[(1-\alpha) \cdot \mathrm{p}_{\mathrm{a}}{ }^{\mathrm{m}} \cdot \mathrm{p}_{\mathrm{u}}{ }^{\mathrm{c}}\right] / \mathrm{P}^{2}$, expression we will note $\ll \mathrm{A} », \mathrm{~A}>0$.

We can show, using equation (18') and the implicit function theorem:

$\frac{d L_{a}}{d d_{a}}=\frac{f^{\prime}\left(L_{a}\right) \cdot F \cdot A-w_{u} \cdot E_{u}^{\prime}\left(d_{a}\right)}{P_{a} \cdot\left[f^{\prime}\left(L_{a}\right)-f^{\prime \prime}\left(L_{a}\right) \cdot F\right]}>0$

it can also be shown that:

$$
\frac{d w_{a}}{d d_{a}}=A \cdot f^{\prime}\left(L_{a}\right)+\frac{d f^{\prime}\left(L_{a}\right)}{d d_{a}} \cdot P_{a}=A \cdot f^{\prime}\left(L_{a}\right)+f^{\prime \prime}\left(L_{a}\right) \cdot \frac{d L_{a}}{d d_{a}} \cdot P_{a}
$$




$$
\frac{d w_{a}}{d d_{a}}=\frac{A \cdot\left[f^{\prime}\left(L_{a}\right)\right]^{2}-f^{\prime \prime}\left(L_{a}\right) \cdot E_{u}^{\prime}\left(d_{a}\right) \cdot w_{u}}{f^{\prime}\left(L_{a}\right)-f^{\prime \prime}\left(L_{a}\right) \cdot F}>0
$$

if and only if :

$$
A \cdot\left[f^{\prime}\left(L_{a}\right)\right]^{2}>f^{\prime \prime}\left(L_{a}\right) \cdot E_{u}^{\prime}\left(d_{a}\right) \cdot w_{u}
$$

that is:

$$
1>\frac{1}{G(\alpha)}>\alpha \geq 0
$$

with $G(\alpha) \equiv 1+\frac{P^{2} f^{\prime \prime} w_{u}^{2}\left(1+t_{a}\right)}{\left(1+t_{u}\right)\left(1+d_{u}\right)^{2} p_{u}^{i^{2}} f^{\prime 2} g^{\prime \prime}}>1$

when $\alpha=0$ we get $\alpha \cdot G(\alpha)=0$ and when $\alpha=1, \alpha \cdot G(\alpha)=\mathrm{G}(\alpha)>1$. If we suppose that the function $\mathrm{H}(\alpha)=\alpha \cdot \mathrm{G}(\alpha)$ is a continuous function monotonously increasing on $[0,1]$, there exists a $\alpha^{*} \in[0,1]$ such that if $\alpha<\alpha^{*}$ ( $\alpha$ «small»), condition (23) is satisfied, while if $\alpha>$ $\alpha^{*}(\alpha \ll$ big »), condition (23) is violated. In order to have $\mathrm{H}(\alpha)$ increasing on $[0,1]$ it is necessary and sufficient that $\mathrm{H}^{\prime}=\alpha \cdot \mathrm{G}^{\prime}+\mathrm{G}>0$, that means that the elasticity of $\mathrm{G}$ respectively to $\alpha$ must be superior to $-1\left(G^{\prime}>0\right.$ or $G^{\prime}<0$ but $\left.\left|\mathrm{e}_{\mathrm{G} / \alpha}\right|<1\right)$.

In addition, we show that :

$\mathrm{dL}_{\mathrm{u}} / \mathrm{dd}_{\mathrm{a}}=1 / \mathrm{w}_{\mathrm{a}}^{2} \cdot\left[\mathrm{E}_{\mathrm{u}}\left(\mathrm{d}_{\mathrm{a}}\right) \cdot \mathrm{w}_{\mathrm{a}} \cdot \mathrm{w}_{\mathrm{u}}+\left(\mathrm{hQ} \mathrm{i} /(1-\mathrm{h})-\mathrm{E}_{\mathrm{u}} \cdot \mathrm{w}_{\mathrm{u}}\right) \cdot \mathrm{dw}_{\mathrm{a}} / \mathrm{dd}_{\mathrm{a}}\right]$

This expression is necessarily negative if $\mathrm{dw}_{\mathrm{a}} / \mathrm{dd}_{\mathrm{a}}$ is positive, i.e. under condition (24) $(\alpha$ small).

Moreover, $\mathrm{L}_{\mathrm{e}}=\mathrm{Q}_{\mathrm{e}} / \mathrm{w}_{\mathrm{a}}$ (equation 4) thus:

Sign $\left(\mathrm{dL}_{\mathrm{e}} / \mathrm{dd}_{\mathrm{a}}\right)=-\operatorname{Sign}\left(\mathrm{dw}_{\mathrm{a}} / \mathrm{dd}_{\mathrm{a}}\right)$.

In equation (16) all the parameters are independent of $d_{a}$, except $w_{a}$, thus:

Sign $\left(\mathrm{dL}_{\mathrm{i}} / \mathrm{dd}_{\mathrm{a}}\right)=-\operatorname{Sign}\left(\mathrm{dw}_{\mathrm{a}} / \mathrm{dd}_{\mathrm{a}}\right)$.

When $\alpha$ violates condition (24) ( $\alpha$ big) then $\mathrm{dL}_{\mathrm{i}} / \mathrm{dd}_{\mathrm{a}}, \mathrm{dL}_{\mathrm{e}} / \mathrm{dd}_{\mathrm{a}}, \mathrm{dL}_{\mathrm{a}} / \mathrm{dd}_{\mathrm{a}}$ are positive, then $\mathrm{d}\left(\mathrm{L}_{\mathrm{i}}+\mathrm{L}_{\mathrm{e}}+\mathrm{L}_{\mathrm{a}}\right) / \mathrm{dd}_{\mathrm{a}}$ is positive, and $\mathrm{dL}_{\mathrm{u}} / \mathrm{dd}_{\mathrm{a}}$ is negative (by virtue of (7)). It follows that, whatever is the value of $\alpha, \mathrm{dL}_{\mathrm{u}} / \mathrm{dd}_{\mathrm{a}}$ is negative.

In summary, if $\mathrm{d}_{\mathrm{a}}$ decreases (liberalization of agriculture):

\begin{tabular}{|l|l|l|l|l|l|}
\hline & $\mathrm{L}_{\mathrm{a}}$ & $\mathrm{L}_{\mathrm{i}}$ & $\mathrm{L}_{\mathrm{e}}$ & $\mathrm{L}_{\mathrm{u}}$ & $\mathrm{E}_{\mathrm{u}}$ \\
\hline$\alpha$ big & decreases & decreases & decreases & increases & increases \\
\hline$\alpha$ small & decreases & increases & increases & increases & increases \\
\hline
\end{tabular}

When $\mathrm{d}_{\mathrm{a}}$ decreases, internal (rural-urban) migration always increases $\left(\mathrm{L}_{\mathrm{a}}\right.$ always decreases, $\mathrm{L}_{\mathrm{u}}+\mathrm{L}_{\mathrm{i}}=\mathrm{L}-\left(\mathrm{L}_{\mathrm{a}}+\mathrm{L}_{\mathrm{e}}\right)$ always increases $)$. By contrast, international migration $\mathrm{L}_{\mathrm{e}}$ can increase or decrease, depending on the value of $\alpha$. When $\alpha$ is small, the liberalization has a positive effect on international migration, while it is the opposite when $\alpha$ is big. So we can say that trade and migration are complementary when $\alpha$ is small, while they are substitutable when $\alpha$ is big. 
A last question is how does $(\mathrm{Lu}-\mathrm{Eu})$ (the number of unemployed people) change when $\mathrm{d}_{\mathrm{a}}$ lowers?

We can show that:

$\frac{d\left(L_{u}-E_{u}\right)}{d d_{a}}=\frac{\left[\frac{d E_{u}}{d d_{a}} \cdot w_{a} \cdot\left(w_{u}-w_{a}\right) \cdot(1-h)\right]+\left[\frac{d w_{a}}{d d_{a}} \cdot\left[h \cdot Q_{i}-(1-h) \cdot E_{u} \cdot w_{u}\right]\right]}{(1-h) \cdot w_{a}^{2}}$

the first term of the numerator is necessarily negative, as $E_{u}{ }^{\prime}\left(d_{a}\right)<0$ (cf. 20) while the second term may be negative or positive. That second term is composed by two factors. The first one, $\mathrm{dw}_{\mathrm{a}} / \mathrm{dd}_{\mathrm{a}}$ may be positive or negative, depending on whether $\alpha$ is (respectively) small or big (cf. supra equations 23 and 24), and the second one is necessarily negative if condition (19) holds. It results that if $\mathrm{dw}_{\mathrm{a}} / \mathrm{dd}_{\mathrm{a}}$ is positive ( $\alpha$ small) $\mathrm{L}_{\mathrm{u}}-\mathrm{E}_{\mathrm{u}}$ increases when $\mathrm{d}_{\mathrm{a}}$ decreases, which means that agricultural liberalization increases the number of unemployed. When $\mathrm{dw}_{\mathrm{a}} / \mathrm{dd}_{\mathrm{a}}$ is negative, expression (26) has in the numerator a negative and a positive term. Expression (26) may then be positive, if the second (positive) term is bigger than the first one.

In summary, we will have, if $d_{a}$ decreases (liberalization of agriculture):

\begin{tabular}{|l|l|l|l|l|l|}
\hline & $\mathrm{L}_{\mathrm{a}}$ & $\mathrm{L}_{\mathrm{i}}$ & $\mathrm{L}_{\mathrm{e}}$ & $\mathrm{L}_{\mathrm{u}}$ & $\mathrm{L}_{\mathrm{u}}-\mathrm{E}_{\mathrm{u}}$ \\
\hline$\alpha$ big & decreases & decreases & decreases & increases & $?$ \\
\hline$\alpha$ small & decreases & increases & increases & increases & increases \\
\hline
\end{tabular}

\section{1-22: Consequences of an increase in $t_{a}$ and $t_{u}$}

Liberalization means a drop in the resources of the State, insofar as taxes on international trade are an important percentage of the resources of the State in several developing countries (see table 1).

Table 1: Structure of central government revenues in 2001 for 9 developing countries and mean values for Middle Income economies (as a percentage of total current revenue)

\begin{tabular}{|lllllll|}
\hline Country & $\begin{array}{l}\text { Taxes on } \\
\text { Income, profits } \\
\text { and capital } \\
\text { gains }\end{array}$ & $\begin{array}{l}\text { Social Security } \\
\text { Taxes }\end{array}$ & $\begin{array}{l}\text { Taxes on goods and } \\
\text { services }\end{array}$ & $\begin{array}{l}\text { Taxes on } \\
\text { International } \\
\text { Trade }\end{array}$ & Other Taxes & Non tax Revenue \\
Algeria & 70 & 0 & 8 & 11 & 1 & 10 \\
China & 6 & 0 & 75 & 10 & 4 & 6 \\
Egypt (1997) & 22 & 0 & 17 & 13 & 12 & 37 \\
India & 29 & 0 & 29 & 18 & 0 & 24 \\
Jordan & 12 & 0 & 36 & 17 & 1 & 10 \\
Mexico & 34 & 10 & 62 & 16 & 3 & 9 \\
Morocco & 24 & 5 & 36 & 11 & 4 & 17 \\
Tunisia & 20 & 17 & 40 & 1 & 7 & \\
Turkey & 35 & 0 & & & 16 & \\
\hline
\end{tabular}




\begin{tabular}{|llll|l|l|}
\hline $\begin{array}{l}\text { Lower Middle } \\
\text { Income } \\
\text { countries (mean } \\
\text { value) }\end{array}$ & 30 & 36 & 9 & 3 & 14 \\
$\begin{array}{l}\text { Upper Middle } 17 \\
\begin{array}{l}\text { Income } \\
\text { countries (mean } \\
\text { value) }\end{array}\end{array}$ & 31 & 37 & 3 & 1 & 10 \\
\hline Source: World Development Indicators 2004 & & & \\
\hline
\end{tabular}

Source: World Development Indicators 2004

It will be thus necessary to increase other taxes in order to compensate the reduction of resources coming from international trade. In this model, we examine the possibility of an increase in the sale taxes and the implications it will have on migrations.

\section{1-221: Consequences of an increase in $t_{a}$.}

$\mathrm{dL}_{\mathrm{a}} / \mathrm{dt}_{\mathrm{a}}$ is given by equation (22) where we replace $\mathrm{A}$ by $\mathrm{dP}_{\mathrm{a}} / \mathrm{dt}_{\mathrm{a}}$ and $\mathrm{E}_{\mathrm{u}}{ }^{\prime}\left(\mathrm{d}_{\mathrm{a}}\right)$ by $\mathrm{E}_{\mathrm{u}}{ }^{\prime}\left(\mathrm{t}_{\mathrm{a}}\right)$. In the same way, $\mathrm{dw}_{\mathrm{a}} / \mathrm{dt}_{\mathrm{a}}$ is given by equation (23) where we replace $A$ et $\mathrm{E}_{\mathrm{u}}{ }^{\prime}\left(\mathrm{d}_{\mathrm{a}}\right)$ similarly. We also show that:

$\mathrm{dP}_{\mathrm{a}} / \mathrm{dt}_{\mathrm{a}}=-\alpha \mathrm{P}_{\mathrm{a}}^{2}<0$ and $\mathrm{dE}_{\mathrm{u}} / \mathrm{dt}_{\mathrm{a}}=\left[\alpha \cdot \mathrm{p}_{\mathrm{a}}^{\mathrm{p}} \cdot \mathrm{w}_{\mathrm{u}}\right] /\left[\mathrm{p}_{\mathrm{u}}^{\mathrm{p}} \cdot \mathrm{g},\left(\mathrm{E}_{\mathrm{u}}\right)\right]<0$

$\mathrm{dL}_{\mathrm{a}} / \mathrm{dt}_{\mathrm{a}}$ can be negative or positive, but $\mathrm{dw}_{\mathrm{a}} / \mathrm{dt}_{\mathrm{a}}$ is necessarily negative. Negativity of $\mathrm{dw}_{\mathrm{a}} / \mathrm{dt}_{\mathrm{a}}$ implies positivity of $\mathrm{dL}_{\mathrm{e}} / \mathrm{dt}_{\mathrm{a}}$ and $\mathrm{dL}_{\mathrm{i}} / \mathrm{dt}_{\mathrm{a}}$. That means that when we increase taxes on agricultural good, ceteris paribus, $\mathrm{L}_{\mathrm{e}}$ and $\mathrm{L}_{\mathrm{i}}$ also increase.

Moreover, it can be shown that:

$\operatorname{Sign}\left(d_{\mathrm{a}} / \mathrm{dt}_{\mathrm{a}}\right)=\operatorname{Sign}\left(C \cdot \mathrm{p}_{\mathrm{u}}{ }^{\mathrm{p}} \cdot \mathrm{g}{ }^{\prime}\left(\mathrm{E}_{\mathrm{u}}\right)+\mathrm{w}_{\mathrm{u}}{ }^{2} \cdot \mathrm{P}\right)$ with $\mathrm{C}=\left[\mathrm{E}_{\mathrm{u}} \cdot \mathrm{w}_{\mathrm{u}}+\mathrm{Q}_{\mathrm{i}}+\mathrm{Q}_{\mathrm{e}}\right]$

$\mathrm{g}$ ' $\left(\mathrm{E}_{\mathrm{u}}\right)$ is by hypothesis negative so that the second expression has a negative term and a positive one. It is possible to demonstrate that a necessary and sufficient condition for $\mathrm{dL}_{\mathrm{a}} /$ $\mathrm{dt}_{\mathrm{a}}$ to be negative is:

$\left.\mathrm{Q}_{\mathrm{i}}+\mathrm{Q}_{\mathrm{e}}>-\mathrm{w}_{\mathrm{u}} \cdot\left[\mathrm{E}_{\mathrm{u}}+\mathrm{g}^{\prime}\left(\mathrm{E}_{\mathrm{u}}\right) / \mathrm{g}, \mathrm{E}_{\mathrm{u}}\right)\right]$

The intuitive interpretation of that condition is easy: when taxes increase, formal employment lowers $\left(\mathrm{E}_{\mathrm{u}}{ }^{\prime}\left(\mathrm{t}_{\mathrm{a}}\right)\right.$ negative). So, in order to have a decrease in the work force in agriculture, i.e. to permit a rural-urban migration, the size of informal emigration sectors (both national and foreign) must be big enough to absorb the migratory flow and offer an income level high enough to be attractive.

In summary, when $t_{a}$ increases:

\begin{tabular}{|l|l|l|l|l|c|}
\hline & $\mathrm{L}_{\mathrm{a}}$ & $\mathrm{L}_{\mathrm{i}}$ & $\mathrm{L}_{\mathrm{e}}$ & $\mathrm{E}_{\mathrm{u}}$ & $\mathrm{W}_{\mathrm{a}}$ \\
\hline$(27)$ hold & decreases & increases & increases & decreases & decreases \\
\hline (27) doesn't hold & increases & increases & increases & decreases & decreases \\
\hline
\end{tabular}

We can also note that $d\left(\mathrm{~L}_{\mathrm{u}}-\mathrm{E}_{\mathrm{u}}\right) / \mathrm{dt}_{\mathrm{a}}$ is given by equation (26) where we replace $\mathrm{E}_{\mathrm{u}}{ }^{\prime}\left(\mathrm{d}_{\mathrm{a}}\right)$ by $\mathrm{E}_{\mathrm{u}}$ ' $\left(\mathrm{t}_{\mathrm{a}}\right)$ and $\mathrm{dw}_{\mathrm{a}} / \mathrm{dd}_{\mathrm{a}}$ by $\mathrm{dw}_{\mathrm{a}} / \mathrm{dt}_{\mathrm{a}}$. $\mathrm{E}_{\mathrm{u}}{ }^{\prime}\left(\mathrm{t}_{\mathrm{a}}\right)$ like $\mathrm{E}_{\mathrm{u}}{ }^{\prime}\left(\mathrm{d}_{\mathrm{a}}\right)$ is negative, but $\mathrm{dw}_{\mathrm{a}} / \mathrm{dt}_{\mathrm{a}}$ is necessarily negative, while $\mathrm{dw}_{\mathrm{a}} / \mathrm{dd}_{\mathrm{a}}$ may be positive or negative, depending on whether $\alpha$ is (respectively) small or

\footnotetext{
${ }^{4}$ note that a sufficient, but not necessary, condition of (27) is: $E_{u}>-g^{\prime}\left(E_{u}\right) / g$ '’ $\left(E_{u}\right)$, i.e. function g' $\left(E_{u}\right)$ must have an elasticity relatively to $\mathrm{E}_{\mathrm{u}}$ inferior to -1 (superior to one in absolute value). Condition (27) may also be rewritten $C / w_{u}>-g^{\prime}\left(E_{u}\right) / g^{\prime},\left(E_{u}\right)$, or F.q $>-g^{\prime}\left(E_{u}\right) / g, '\left(E_{u}\right)$.
} 
big. As a consequence we cannot say in the general case if $d\left(\mathrm{~L}_{\mathrm{u}}-\mathrm{E}_{\mathrm{u}}\right) / \mathrm{dt}_{\mathrm{a}}$ is positive or negative.

\section{1-222: Consequences of an increase in $t_{u}$}

It can be shown that:

$\mathrm{dP}_{\mathrm{a}} / \mathrm{dt}_{\mathrm{u}}=-\left[\mathrm{p}_{\mathrm{a}}^{\mathrm{p}} \cdot \mathrm{p}_{\mathrm{u}}{ }^{\mathrm{p}} \cdot(1-\alpha)\right] / \mathrm{P}^{2}<0$. We will call this expression $\mathrm{X}$.

$\mathrm{dE}_{\mathrm{u}} / \mathrm{dt}_{\mathrm{u}}=\left[(1-\alpha) \cdot \mathrm{w}_{\mathrm{u}}\right] /\left[\mathrm{g},\left(\mathrm{E}_{\mathrm{u}}\right)\right]<0$. We will call this expression $\mathrm{Y}$.

Using (18') and the implicit function theorem, we demonstrate that:

$\frac{d L_{a}}{d t_{u}}=\frac{a \cdot h \cdot f^{\prime}\left(L_{a}\right)}{w_{u} \cdot\left[f^{\prime}\left(L_{a}\right)-f^{\prime \prime}\left(L_{a}\right) \cdot F\right]}+\frac{F \cdot f^{\prime}\left(L_{a}\right) \cdot X-w_{u} \cdot Y-a}{P_{a} \cdot\left[f^{\prime}\left(L_{a}\right)-f^{\prime \prime}\left(L_{a}\right) \cdot F\right]}$

This expression is strictly negative if and only if:

$a>\frac{Y \cdot w_{u}-X \cdot F \cdot f^{\prime}\left(L_{a}\right)}{h \cdot q-1}=\mathrm{a}_{1}{ }^{5}$

By replacing $\mathrm{X}$ et $\mathrm{Y}$ with their value, one gets:

C. $p_{u}^{p} \cdot g{ }^{\prime \prime}\left(E_{u}\right)+w_{u}^{2} \cdot P<Z$

with $\quad Z \equiv a \cdot \frac{P .(h \cdot q-1) \cdot g^{\prime \prime}\left(E_{u}\right)}{(1-\alpha)}$

In the general case it can be shown that the negativity condition is:

$Q_{i}\left(t_{u}\right)+Q_{e}>\frac{Z}{p_{u}^{p} \cdot g^{\prime \prime}\left(E_{u}\right)}-w_{u} \cdot\left(g^{\prime}\left(E_{u}\right) / g^{\prime \prime}\left(E_{u}\right)+E_{u}\right)$

This condition looks like condition (27) and is equivalent to (27) when a=0 (i.e. when $\mathrm{Q}_{\mathrm{i}}$ does not depend on $t_{u}$ ). When a is positive, $\mathrm{Z}$ is also positive and the right member of (31) is smaller $(\mathrm{g}$ " $<0)$ than the right member of $(27)$ : equation (31) may be satisfied even if $(27)$ doesn't hold. This means that when $\mathrm{Q}_{\mathrm{i}}$ depends positively on $\mathrm{t}_{\mathrm{u}}$ it is more frequent to have a raise of $\mathrm{t}_{\mathrm{u}}$ creating a rural-urban migration.

It can be also shown, thanks to equation (1), that:

$\frac{d w_{a}}{d t_{u}}=X \cdot f^{\prime}\left(L_{a}\right)+f^{\prime \prime}\left(L_{a}\right) \cdot P_{a} \frac{d L_{a}}{d t_{u}}$

By replacing $\mathrm{dL}_{\mathrm{a}} / \mathrm{dt}_{\mathrm{u}}$ by its value we obtain:

\footnotetext{
${ }^{5}: a_{1}$ may be positive or negative. Condition (27) is necessary and sufficient to have $a_{1}$ negative. When (27)
} holds, (29) is satisfied for any « $\mathrm{a}$ » superior or equal to zero and so $\mathrm{dL}_{\mathrm{a}} / \mathrm{dt}_{\mathrm{u}}$ is always strictly negative. 


$$
\frac{d w_{a}}{d t_{u}}=\frac{X \cdot f^{\prime}\left(L_{a}\right)^{2}+f^{\prime \prime}\left(L_{a}\right) \cdot\left[a \cdot(h q-1)-w_{u} \cdot Y\right]}{f^{\prime}\left(L_{a}\right)-f^{\prime \prime}\left(L_{a}\right) \cdot F}
$$

This is strictly positive if and only if:

$\mathrm{a}>\frac{X \cdot f^{\prime}\left(L_{a}\right)^{2}-f^{\prime \prime}\left(L_{a}\right) \cdot w_{u} \cdot Y}{f^{\prime \prime}\left(L_{a}\right) \cdot(1-h \cdot q)}=\mathrm{a}_{2} \geq 0$

We demonstrate now that $a_{2} \geq a_{1}$ :

Let us suppose the contrary:

$a_{1}>a_{2}$ implies f', $\left(L_{a}\right)$. F $>$ f' $\left(L_{a}\right)$, but this is impossible as: f' $\left(L_{a}\right) \geq 0 \geq f^{\prime \prime}\left(L_{a}\right) . F$.

It is a consequence of (4) that $\mathrm{L}_{\mathrm{e}}=\mathrm{Q}_{\mathrm{e}} / \mathrm{w}_{\mathrm{a}}$, with $\mathrm{Q}_{\mathrm{e}}$ exogenous. As a result we have:

$\operatorname{Sgn}\left(\mathrm{dL}_{\mathrm{e}} / \mathrm{dt}_{\mathrm{u}}\right)=-\operatorname{Sgn}\left(\mathrm{dw}_{\mathrm{a}} / \mathrm{dt}_{\mathrm{u}}\right)$

In Summary:

\begin{tabular}{|l|l|l|l|}
\hline Value of $\mathrm{a}$ & $\mathrm{a}<\mathrm{a}_{1}$ & $\mathrm{a}_{1}<\mathrm{a}<\mathrm{a}_{2}$ & $\mathrm{a}_{2}<\mathrm{a}$ \\
\hline Sign of $\left(\mathrm{dL}_{\mathrm{a}} / \mathrm{dt}_{\mathrm{u}}\right)$ & + & - & - \\
\hline Sign of $\left(\mathrm{dw}_{\mathrm{a}} / \mathrm{dt}_{\mathrm{u}}\right)$ & - & - & + \\
\hline Sign of $\left(\mathrm{dL}_{\mathrm{e}} / \mathrm{dt}_{\mathrm{u}}\right)$ & + & + & - \\
\hline
\end{tabular}

We also know by (16) that:

$L_{i}=\frac{Q_{i}}{(1-h) \cdot w_{a}}-\frac{Q_{i} \cdot h}{(1-h) \cdot w_{u}}$

so $\frac{d L_{i}}{d t_{u}}=\frac{a \cdot w_{a} \cdot(1-h q)-Q_{i} \cdot \frac{d w_{a}}{d t_{u}}}{(1-h) \cdot w_{a}{ }^{2}}$

which is strictly positive if and only if:

a. $w_{a} .(1-h q)-Q_{i} \cdot \frac{d w_{a}}{d t_{u}}>0$.

But we know by (33) that:

$\frac{f^{\prime \prime}\left(L_{a}\right) \cdot a \cdot(h q-1)}{f^{\prime}\left(L_{a}\right)-f^{\prime \prime}\left(L_{a}\right) \cdot F}>\frac{d w_{a}}{d t_{u}}$

and so:

$a \cdot w_{a} \cdot(1-h q)-Q_{i} \cdot \frac{d w_{a}}{d t_{u}}>\frac{a \cdot(1-h q) \cdot\left[w_{a} \cdot f^{\prime}\left(L_{a}\right)+\left(Q_{i}-C\right) \cdot f^{\prime \prime}\left(L_{a}\right)\right]}{f^{\prime}\left(L_{a}\right)-f^{\prime \prime}\left(L_{a}\right) \cdot F} \geq 0$

and so we have shown that $\frac{d L_{i}}{d t_{u}}>0$. 
In summary, when $t_{u}$ increases:

\begin{tabular}{|l|l|l|l|l|l|}
\hline & $\mathrm{L}_{\mathrm{a}}$ & $\mathrm{L}_{\mathrm{i}}$ & $\mathrm{L}_{\mathrm{e}}$ & $\mathrm{E}_{\mathrm{u}}$ & $\mathrm{W}_{\mathrm{a}}$ \\
\hline $\mathrm{a}<\mathrm{a}_{1}$ & increases & increases & increases & decreases & decreases \\
\hline $\mathrm{a}_{1}<\mathrm{a}<\mathrm{a}_{2}$ & decreases & increases & increases & decreases & decreases \\
\hline $0 \leq \mathrm{a}_{2}<\mathrm{a}$ & decreases & increases & decreases & decreases & increases \\
\hline
\end{tabular}

We can also note that $d\left(\mathrm{~L}_{\mathrm{u}}-\mathrm{E}_{\mathrm{u}}\right) / \mathrm{dt}_{\mathrm{u}}$ is given by the second member of equation (26) where we replace $\mathrm{E}_{\mathrm{u}}{ }^{\prime}\left(\mathrm{d}_{\mathrm{a}}\right)$ by $\mathrm{E}_{\mathrm{u}}{ }^{\prime}\left(\mathrm{t}_{\mathrm{u}}\right)$ and $\mathrm{dw}_{\mathrm{a}} / \mathrm{dd}_{\mathrm{a}}$ by $\mathrm{dw}_{\mathrm{a}} / \mathrm{dt}_{\mathrm{u}}$ and to which we add a positive expression equal to $\left[\mathrm{a} \cdot \mathrm{h}^{2} /(1-\mathrm{h}) \cdot \mathrm{w}_{\mathrm{u}}\right]$.

$\mathrm{E}_{\mathrm{u}}$ ' $\left(\mathrm{t}_{\mathrm{u}}\right)$ like $\mathrm{E}_{\mathrm{u}}$ ' $\left(\mathrm{d}_{\mathrm{a}}\right)$ is negative, and $\mathrm{dw}_{\mathrm{a}} / \mathrm{dt}_{\mathrm{u}}$ may be positive or negative, depending on whether " $a$ " is (respectively) superior or inferior to $a_{2}$. As in the former case, the sign of $d\left(\mathrm{~L}_{u^{-}}\right.$ $\left.\mathrm{E}_{\mathrm{u}}\right) / \mathrm{dt}_{\mathrm{u}}$ can be positive or negative.

\section{1-23 Synthesis}

Let us analyze now the global effects of a drop in $d_{a}$ financed by an increase in $t_{a}$ or $t_{u}$.

Case $n^{\circ}$ 1: a decrease in $d_{a}$ financed by an increase in $t_{a}$

\begin{tabular}{|l|l|l|l|l|}
\hline & $\mathrm{L}_{\mathrm{a}}$ & $\mathrm{L}_{\mathrm{i}}$ & $\mathrm{L}_{\mathrm{e}}$ & $\mathrm{E}_{\mathrm{u}}$ \\
\hline $\begin{array}{l}\alpha \text { big, (27) satisfied } \\
\text { zone } 1 »\end{array}$ & decreases & $?$ & $?$ & $?$ \\
\hline $\begin{array}{l}\alpha \text { big, (27) not satisfied } \\
\text { «one 2 » }\end{array}$ & $?$ & $?$ & $?$ & $?$ \\
\hline $\begin{array}{l}\alpha \text { small, (27) satisfied } \\
\text { zone 3» }\end{array}$ & decreases & increases & increases & $?$ \\
\hline $\begin{array}{l}\alpha \text { small, (27) not satisfied } \\
\text { zone 4 }\end{array}$ & $?$ & increases & increases & $?$ \\
\hline
\end{tabular}

The undetermined cases are due to the fact that the two effects act contradictorily. However, when $\alpha$ is small we always see an increase of $\mathrm{L}_{\mathrm{i}}$ and $\mathrm{L}_{\mathrm{e}}$, as well as a decrease in $\mathrm{L}_{\mathrm{a}}$ whatever be $\alpha$ when (27) holds.

Case $n^{\circ}$ 2: a decrease in $d_{a}$ financed by an increase in $t_{u}$ 


\begin{tabular}{|l|l|l|l|l|}
\hline & $\mathrm{L}_{\mathrm{a}}$ & $\mathrm{L}_{\mathrm{i}}$ & $\mathrm{L}_{\mathrm{e}}$ & $\mathrm{E}_{\mathrm{u}}$ \\
\hline $\mathrm{a}<\mathrm{a}_{1}, \alpha$ big & $?$ & $?$ & $?$ & $?$ \\
\hline $\mathrm{a}_{1}<\mathrm{a}<\mathrm{a}_{2}, \alpha$ big & decreases & $?$ & $?$ & $?$ \\
\hline $\mathrm{a}_{2}<\mathrm{a}, \alpha$ big & decreases & $?$ & decreases & $?$ \\
\hline${\mathrm{a}<\mathrm{a}_{1}, \alpha \text { small }}$ & $?$ & increases & increases & $?$ \\
\hline $\mathrm{a}_{1}<\mathrm{a}<\mathrm{a}_{2}, \alpha$ small & decreases & increases & increases & $?$ \\
\hline $\mathrm{a}_{2}<\mathrm{a}, \alpha$ small & decreases & increases & $?$ & $?$ \\
\hline
\end{tabular}

Here we insist on the value of $\alpha$ and that of "a". Each time $a>a_{1}$, the combined actions produce an increase in rural-urban migration. When $\alpha$ is small, the two actions always increase employment in informal sector. Besides, international migration necessarily increases for "small $\alpha$ countries", as long as "a" is not too big (i.e., when $a<a_{2}$ ). As a matter of fact, when "a" is very high, that means that national informal sector activity grows a lot as a result of an increase in taxes, and in consequence that sector is going to absorb the flow of migrants coming from the rural sector. Similarly, it is clear that "big $\alpha$ countries" with a big value of "a" $\left(a>a_{2}\right)$ will experience a decrease in international migration in the case we are studying.

\section{1-3: Intuitive interpretation and policy recommendations}

In this section we will give an intuitive interpretation of the results we have seen. Then, we will give some policy recommendations in order to illustrate what one can learn from a Harris-Todaro model like this one. Besides, we provide in annex the value of $\alpha$, i.e. food expenditure as a percentage of total expenditure, for some countries. It is possible to see that South Mediterranean countries, with the exception maybe of Tunisia, have relatively high value of $\alpha$, while countries with low values of $\alpha$ are mostly developed economies, or EastEuropean and Latin-American ones.

1-31: Intuitive functioning of the model

1-311: the effect of a decrease in custom duties $\left(d_{a}\right)$

The value of alpha affects the relation between agricultural liberalization and migrations by virtue of the following device:

Case 1: if alpha is big (at the limit, workers are uniquely paid in agricultural goods)

- the cutting down of agricultural custom duties generates a drop in domestic agricultural prices, which provokes a rise of urban employment, this rise being stronger when agricultural goods have a bigger part in the consumption basket ; 
- if rural population $\left(\mathrm{L}_{\mathrm{a}}\right)$ were set constant, rural real wage $\left(\mathrm{w}_{\mathrm{a}}\right)$ would not lower much, as $\mathrm{P}_{\mathrm{a}}$ does not change a lot if alpha is close to one ;

- But the raise in urban employment increases the expected value of urban income, and that provokes an increase in rural-urban migration ( $\mathrm{L}_{\mathrm{a}}$ decreases);

- The decrease of $\mathrm{L}_{\mathrm{a}}$ generates an increase of $\mathrm{w}_{\mathrm{a}}$, which reduces international emigration and emigration to national informal sector.

\section{Case 2: if alpha is small (at the limit, workers are uniquely paid in manufactured goods)}

- The drop in agricultural custom duties only moderately increases urban employment as the workers do not consume much agricultural goods;

- With a constant $\mathrm{L}_{\mathrm{a}}$, rural real wage $\left(\mathrm{w}_{\mathrm{a}}\right)$ decreases a lot, because the price of the agricultural good lowers and the workers consume essentially manufactured goods;

- The fall in $\mathrm{w}_{\mathrm{a}}$ together with the quasi-stagnation of urban formal employment increases the migratory pressure toward national and foreign informal sectors.

The difference between the two cases is intuitively that:

- In the first case (alpha is big), the increase in urban formal employment is big enough to absorb the migratory flow coming from the rural sector while in the second case (alpha is small), the expansion of urban formal sector is not big enough;

- In the first case, the domestic drop in agricultural prices does not decrease much real wage in the rural sector because the workers only consume the agricultural good they produce. In this case migratory pressure does not come from the worsening of rural situation, but from the improvement of the urban formal employment. The improvement of the urban formal employment generates positive effects on the rural sector and a decrease of informal employment, both foreign and national.

- By contrast, in the second case (alpha is small), the workers produce an agricultural good whose price is lowering and consume essentially manufactured goods whose price is constant. The deterioration of internal terms of exchange (ratio of agricultural prices on manufactured prices) generates a decrease of real wages in the rural sector. On the opposite side, the urban formal sector does not experiment a notable expansion. The rural-urban migration is in this case the consequence of a deterioration of rural situation. As formal urban employment did not increase, that means an increase of foreign and national informal employment.

\section{1-312: the effect of an increase in taxes}

It is important to make the difference between the case of an increase in taxes that affect the agricultural good and the case of a growth of the taxes that bear on the manufactured good. As a matter of fact, in the second case, the fiscal increase will have an expansive effect on the national informal sector, which will develop itself at the expense of the formal sector, while in the first case this effect will not appear.

Case 1: an increase in $t_{a}$ 
In order to have an increase in $t_{a}$ implying a decrease in rural employment, it is necessary and sufficient to have condition (C) satisfied, as demonstrated above (see equation 27):

(C): $\mathrm{Q}_{\mathrm{i}}+\mathrm{Q}_{\mathrm{e}}>\phi\left(E_{u}\right)$, where $\mathrm{Q}_{\mathrm{i}}$ is the size of the national informal sector, $\mathrm{Q}_{\mathrm{e}}$ is the size of foreign informal sector (emigration sector), and $\mathrm{E}_{\mathrm{u}}$ is urban formal employment.

This condition means that an increase in agricultural taxes will not have a negative effect on rural employment unless the sum of the sizes of the foreign and national informal sectors is big enough. As a matter of fact, the increase in agricultural taxes generates an increase in wage costs and consequently a decrease in urban formal employment. It is thus necessary to have the informal sectors big enough to explain that the rural workers leave the countryside.

\section{Case $2:$ an increase in $t_{u}$}

In this case, $Q_{i}$ is not anymore exogenous as it varies in function of $t_{u}$ (when $t_{u}$ increases, $Q_{i}$ also increases). If we want to have $\mathrm{L}_{\mathrm{a}}$ decreasing in response to an increase in $t_{u}$, it is necessary and sufficient to have $\mathrm{Q}_{\mathrm{i}}$ "sufficiently" sensitive to the variation in $\mathrm{t}_{\mathrm{u}}$ (in order to have (C) satisfied). So it is necessary to have "a" (i.e. $\mathrm{dQ}_{\mathrm{i}} / \mathrm{dt}_{\mathrm{u}}$ ) "sufficiently" big in order to have the increase in $t_{u}$ provoking a decrease in $L_{a}$ (rural employment). That explains the condition: $\mathrm{a}>\mathrm{a}_{1}$.

If we are interested in the evolution of international migration, the important point is the effect of the increase in $t_{u}$ on the real agricultural wage $w_{a}$. This effect takes place by two channels: on one hand, the effect of $t_{u}$ on the general price level and, on the other hand, the effect of $\mathrm{t}_{\mathrm{u}}$ on rural employment $\mathrm{L}_{\mathrm{a}}$ via its effect on $\mathrm{Q}_{\mathrm{i}}$ (cf. supra). We demonstrate that when $\mathrm{a}<\mathrm{a}_{2}$ the sign of $\mathrm{dw}_{\mathrm{a}} / \mathrm{dt}_{\mathrm{u}}$ is negative. As we have set that $\mathrm{L}_{\mathrm{e}}=\mathrm{Q}_{\mathrm{e}} / \mathrm{w}_{\mathrm{a}}$ we can deduce that when $\mathrm{a}<\mathrm{a}_{2}, \mathrm{~L}_{\mathrm{e}}$ increases if $\mathrm{t}_{\mathrm{u}}$ increases (and inversely if $\mathrm{a}>\mathrm{a}_{2}$ ).

\section{1-32: Policy recommendations}

In order to make policy recommendations, we will identify first some goals that can be pursued by governments. A first goal could be political stability which can signify for the country of origin of emigration (let us say, the South) a low level of urban unemployment. Another objective could be as we have said budgetary equilibrium, so that a reduction in custom duties must be balanced by a raise in other taxes, such as sales taxes. Liberalization of trade is also an objective, and that includes liberalization of agricultural trade. From the point of view of destination country (the North) a control of immigration is also an objective, that could be for an economic reason (to impede a raise of unemployment in the North) or for a sociological one (to prevent a drop in social capital). Finally we could identify "social clause" as an attempt to limit the size of informal sector in the South, insofar as informal sector does not respect any labor regulation and can have a salary level below the minimum wage.

a) When alpha is "small", liberalization of agricultural trade will foster international migration, will develop the national informal sector and will increase the number of unemployed people. If we finance the drop in custom duties by an agricultural tax, the effect of the raise in taxes will be to increase further emigration and national informal sector, and to decrease real rural wage and the number of people employed in urban formal sector. In 
summary, conditions are going to get worst but it will permit to maintain budgetary equilibrium. Things are similar when budgetary equilibrium is obtained thanks to a raise in manufactured sales tax $t_{u}$, except when « $a$ » is sufficiently big $\left(a>a_{2} \geq 0\right)$. This case means that $\mathrm{Q}_{\mathrm{i}}$ (size of national informal sector) is positively related and sufficiently sensitive to $t_{\mathrm{u}}$, so that the expansion of national informal sector in response of a raise in $t_{u}$ will be sufficient to absorb the rural-urban migration, and emigration toward foreign informal sector could decrease (but not necessarily, since the effect of a drop in $\mathrm{d}_{\mathrm{a}}$, ceteris paribus, is an increase in international migration).

In the case of a "small alpha country", liberalization of agricultural products is not consistent with other objectives like budgetary equilibrium, control of migrations and social clause. It is possible to maintain liberalization and budgetary equilibrium if we remove the objectives of control of migration and social clause. If we finance the reduction in custom duties by a raise in $t_{u}$ and if the size of national informal sector is positively related and sufficiently sensitive to $t_{u}$ it is possible to have an expansion of informal sector big enough to avoid an increase in international migration. So the lesson of the model is that in the case of a East-European country or a Latin American country, where $\alpha$ is likely to be small, it is difficult to pursue at the same time the objectives of a control of migration, liberalization, budgetary equilibrium, and reduction of national informal sector (as a kind of "social clause").

b) When alpha is big, as in the case of South-Mediterranean countries for example, situation is better. As a matter of fact, when $\alpha$ is big, liberalization of agriculture is compatible with a decrease in international emigration and in the size of informal sector, and it does not necessarily imply an increase in the number of unemployed. Taking into account the effects of a rise in taxes the previsions may be less optimistic, since the increase in sales taxes will generally have a expansive effect on the informal sector and the international migration (except in the case of a high positive value of "a", i.e. $a>a_{2} \geq 0$, where international migration can decrease). So the combined effect of a reduction in custom duties and an increase in sales taxes is not clear. Nevertheless, even if the combined effect is not going in the sense of a better control of migration and a lesser size of informal sector, it is possible to drop the budgetary equilibrium objective, and still pursue the three others.

\section{2 - The teaching of new approaches of migrations}

The model developed above is based on the Harris-Todaro tradition, so, the only reason to migrate is a difference between the expected value of income in various sectors. Now, we will intend to complete the preceding approach by considering four aspects which are not present in the Harris-Todaro framework: the cost of migration (section 2-1), the attitude toward risk (section 2-2), the relative deprivation hypothesis (section 2-3) and the role of social capital (section 2-4). 


\section{2-1: Impact of migration costs}

\section{2-11: analysis}

To migrate is not free, it is thus necessary to take into account the cost of migrating, in particular in order to define if, when a developing country get richer, migration decrease or increase. It is clear that when a country becomes richer, its inhabitants have less incitation to migrate, but, at the same time, they are more capable to assume the cost of migration. We will see this phenomenon in a model inspired by Schiff (1994).

Let us suppose that there are two goods:

- one durable and indivisible, capital good

- one perishable, consumption good

The individuals are paid in perishable goods. The perishable good produced in year y can be stored during the entire year y but completely disappears in $y+1$. So the only way to store goods for more than one year is to convert them into the durable good. The durable good is indivisible and one unit of this good costs $\mathrm{x}$ units of perishable good. So in order to store wealth it is necessary to save at least x units of perishable goods, because if not, it is not possible to convert perishable goods in durable good. The durable good is a capital good, and so, detention of one unit of durable good give each period r.x units of perishable goods to its bearer, $r$ being the rate of interest.

There are two countries in this model: the South and the North. In the South, the annual wage is $\mathrm{W}_{\mathrm{s}}$, while in the North, it is $\mathrm{W}_{\mathrm{n}}$ with $\mathrm{W}_{\mathrm{n}}>\mathrm{W}_{\mathrm{s}}$. In order to stay alive, an individual must spend $\mathrm{W}_{\mathrm{p}}$, which means that $\mathrm{W}_{\mathrm{p}}$ is the wage of subsistence. We suppose $\mathrm{W}_{\mathrm{s}}>\mathrm{W}_{\mathrm{p}}$. If $\left[\mathrm{W}_{\mathrm{s}}-\right.$ $\mathrm{W}_{\mathrm{p}}$ ] is inferior to $\mathrm{x}$, it is not worth saving because the quantity of perishable good that can be saved is not enough to buy a durable good. So, it is more rational to consume the whole salary $\mathrm{W}_{\mathrm{s}}$. But if $\left[\mathrm{W}_{\mathrm{s}}-\mathrm{W}_{\mathrm{p}}\right]$ exceeds $\mathrm{x}$, it may be a good strategy to save and buy one or more units of durable good.

In this model it is possible to migrate from the South to the North in order to have the benefit of a higher salary, but migration has a cost. We suppose for simplicity that cost of migration is one unit of durable good. So, in order to migrate, an individual must save $\mathrm{x}$ units of perishable good, buy one unit of durable good and use it to pay the cost of migration. We have supposed that salary in the North is higher than salary in the South, so that $\left[\mathrm{W}_{\mathrm{n}}-\mathrm{W}_{\mathrm{s}}\right]>0$, but if this difference is inferior to r.x, i.e. if $\mathrm{W}_{\mathrm{n}}<\mathrm{W}_{\mathrm{s}}+$ r.x it is not rational to migrate, as the cost of migration is one unit of durable good, and detention of one unit of durable good gives r.x unit of perishable goods as an interest at each period. So if $\mathrm{W}_{\mathrm{n}}<\mathrm{W}_{\mathrm{s}}+$ r.x the better strategy is not to migrate, but rather to buy one unit of durable good and keep it, while working in the South for a wage $\mathrm{W}_{\mathrm{s}}$. At the opposite, if $\mathrm{W}_{\mathrm{n}}>\mathrm{W}_{\mathrm{s}}+\mathrm{r}$.x it is more rational to use the unit of durable good in order to pay the cost of migration, and enjoy a salary of $W_{n}$ rather than $W_{s}+$ r.x. So, in summary, there are three possible situations:

Case 1: $\left[\mathrm{W}_{\mathrm{s}}-\mathrm{W}_{\mathrm{p}}\right]<\mathrm{x}$ : the individual cannot afford to migrate

Case 2: $\mathrm{W}_{\mathrm{n}}-\mathrm{r} . \mathrm{x}>\mathrm{W}_{\mathrm{s}}>\mathrm{W}_{\mathrm{p}}+\mathrm{x}$ : the individual can pay the cost of migration and has an advantage in migrating, so that he or she migrates from South to North 
Case 3: $\mathrm{W}_{\mathrm{s}}>\mathrm{W}_{\mathrm{p}}+\mathrm{x}$ and $\mathrm{W}_{\mathrm{s}}>\mathrm{W}_{\mathrm{n}}-$ r.x: the individual could pay for migration but he prefers to buy one unit of durable good and keep it, and work in the South. In this case, the individual will not migrate.

Note that it is possible to have $\mathrm{W}_{\mathrm{p}}+\mathrm{x}>\mathrm{W}_{\mathrm{n}}-\mathrm{r} . \mathrm{x}$, or $\mathrm{x} .(1+\mathrm{r})>\mathrm{W}_{\mathrm{n}}-\mathrm{W}_{\mathrm{p}}>0$, so that case 2 do not even exist. But this means that $\mathrm{W}_{\mathrm{n}}$ is very close to subsistence wage, and/or that cost of migration $\mathrm{x}$ is very high and/or the rate of interest $\mathrm{r}$ is very high. If this is not the case, case 2 will exist.

Note also that it is possible to have $\left[\mathrm{W}_{\mathrm{s}}-\mathrm{W}_{\mathrm{p}}\right] \geq 2 \mathrm{x}$, and in that case it will be possible for an individual in the South to buy two durable goods or more. In this case, the decision will still be to migrate if $\mathrm{W}_{\mathrm{s}}<\mathrm{W}_{\mathrm{n}}-$ r.x and to stay in the South if $\mathrm{W}_{\mathrm{s}}>\mathrm{W}_{\mathrm{n}}-$ r.x. As a matter of fact, if we have $\left[\mathrm{W}_{\mathrm{s}}-\mathrm{W}_{\mathrm{p}}\right]=\mathrm{n} . \mathrm{x}$ (with $\mathrm{n}$ a natural number), the individual who migrates will have a revenue of $\mathrm{W}_{\mathrm{n}}+(\mathrm{n}-1)$.rx and the individual who does not migrate will have $\mathrm{W}_{\mathrm{s}}+$ n.r.x, so that the agent will migrate if $\mathrm{W}_{\mathrm{s}}<\mathrm{W}_{\mathrm{n}}-$ r.x.

If case 2 exists, it is clear that when South Country is getting richer, so that the salary $\mathrm{W}_{\mathrm{s}}$ increases and get closer to $\mathrm{W}_{\mathrm{n}}$, there will be two stages in migration:

Stage 1 (case 1): there is no migration

Stage 2 (case 2): migration increases as the southern country get richer and can afford the migration cost

Stage 3 (case 3): migration stops when migration is not any more attractive because the difference between the salary in the South and the salary in the North is not sufficient to compensate the cost of migrating.

Let us now illustrate the model by a numerical example: we suppose that $\mathrm{W}_{\mathrm{p}}=10$ and $\mathrm{W}_{\mathrm{n}}=50$, the other values change as indicate in table 2 :

Table 2: numerical example on costs of migration

\begin{tabular}{|c|c|c|c|}
\hline \multicolumn{2}{|r|}{$\mathrm{x}=20$ and $\mathrm{r}=20 \%$} & \multicolumn{2}{|r|}{$\mathrm{x}=30$ and $\mathrm{r}=50 \%$} \\
\hline $\begin{array}{c}\text { Value of } \\
\mathrm{W}_{\mathrm{s}}\end{array}$ & $\begin{array}{l}\begin{array}{l}\text { Decision of migration or no- } \\
\text { migration }\end{array} \\
\end{array}$ & $\begin{array}{c}\text { Value of } \\
\mathrm{W}_{\mathrm{s}}\end{array}$ & $\begin{array}{l}\text { Decision of migration or no- } \\
\text { migration }\end{array}$ \\
\hline $\begin{array}{c}20 \\
\text { (stage 1) }\end{array}$ & $\begin{array}{l}{\left[\mathrm{W}_{\mathrm{s}}-\mathrm{W}_{\mathrm{p}}\right]=10<\mathrm{x} \text { : the individuals }} \\
\text { cannot afford to migrate }\end{array}$ & $\begin{array}{c}20 \\
\text { (stage 1) }\end{array}$ & $\begin{array}{l}{\left[\mathrm{W}_{\mathrm{s}}-\mathrm{W}_{\mathrm{p}}\right]=10<\mathrm{x} \text { : the individuals }} \\
\text { cannot afford to migrate }\end{array}$ \\
\hline $\begin{array}{c}35 \\
\text { (stage 2) }\end{array}$ & $\begin{array}{l}\mathrm{W}_{\mathrm{n}}-\mathrm{r} \cdot \mathrm{x}=46>\mathrm{W}_{\mathrm{s}}>\mathrm{W}_{\mathrm{p}}+\mathrm{x}=30: \\
\text { individuals migrate }\end{array}$ & \multirow[t]{2}{*}{$\begin{array}{c}45 \\
\text { (stage 3) }\end{array}$} & \multirow{2}{*}{$\begin{array}{l}\mathrm{W}_{\mathrm{s}}>\mathrm{W}_{\mathrm{p}}+\mathrm{x}=40>\mathrm{W}_{\mathrm{n}}-\mathrm{r} \cdot \mathrm{x}=35 \text { : } \\
\text { individuals can pay the cost of } \\
\text { migration but they have no incentive } \\
\text { to migrate because they can earn } 60 \\
=\mathrm{W}_{\mathrm{s}}+\mathrm{r} . \mathrm{x} \text { being in the South while } \\
\text { only } 50 \text { in the North. }\end{array}$} \\
\hline $\begin{array}{c}48 \\
\text { (stage 3) }\end{array}$ & $\begin{array}{l}\mathrm{W}_{\mathrm{s}}>\mathrm{W}_{\mathrm{n}}-\mathrm{r} . \mathrm{x}=46>\mathrm{W}_{\mathrm{p}}+\mathrm{x}=30 \text { : } \\
\text { individuals have no more incentive } \\
\text { to migrate and migration stops. }\end{array}$ & & \\
\hline
\end{tabular}

\section{2-12: policy recommendations}

If we suppose that case 2 exists, i.e. if we suppose that the salary in the North is not too close to subsistence wage, if the cost of migration is not too high relatively to the northern salary, 
and if interest rate is not too high either, then, when the salary in the South increases, migration will raise first and then will stop. So during what we have called "stage 2", there is a temporary increase in migration. In stage 3, migration stops, but there is no return migration, so the global effect of the process is a permanent increase in the stock of migrants in the North. As a result, more trade will imply more migration because free trade will imply an increase in the southern salary (factor price equalization). So, it appears that when cost of migration is taken into account, trade and migrations are complementary and not substitutable as it was the case in the classic model of Mundell (1957).

\section{2-2: Attitude toward risk}

\section{2-21: analysis}

In the basic Harris-Todaro model, going from rural sector to urban sector is renouncing to certainty in order to take a risk. As a matter of fact, the income in the rural sector is supposed to be known with certainty, while in the urban sector, an individual has a certain probability to get a formal job and a certain probability to be unemployed. In spite of that, it can be sustained that an individual could be induced to leave the countryside, even if he is riskadverse, if there is a sufficient risk-premium, i.e. if the formal wage is big enough. Fields (1975) note for example that the urban income is frequently two times more than the rural revenue, and that the employment rate is rarely inferior to $80 \%$ in the city. So if an individual has a utility function in the uncertainty $\mathrm{u}(\mathrm{x})=\sqrt{x}$ and if $\mathrm{y}$ is the rural income, the expected utility in urban activity is $0.8 \sqrt{2 y}$, which is equal to $1.13 \sqrt{y}$ and is superior to $\sqrt{y}$.

Nevertheless, the vision of rural activity as risk-free is obviously misleading. Levhari and Stark (1982) or Stark (1991) note that rural activity is risky, because revenues depend on climatic conditions which are intrinsically variables. On the other hand, urban activity is risky on the short term, but after a first phase of job search, it provides a salary probably more stable than in the countryside, and, so, going to the city could be viewed on the long term as a diminution of risk. So, risk adverse individuals could be incited to migrate if they don't discount too much future utilities.

This point of view can be illustrated by an example:

(i) in case of migration, the revenue is 100 if one finds a formal work and of 20 if one does not find such a job. The probability of finding a formal work is supposed to be of $50 \%$ on the short term but it is $80 \%$ in the long run.

(ii) in case of no-migration, the income is 60 with a probability of $50 \%$ and of 40 with the complementary probability, in the short run or in the long run.

Let us suppose the individual discount future utilities with a factor $\beta$ and that the utility function is $\mathrm{u}(\mathrm{x})=\mathrm{L}_{\mathrm{n}}(\mathrm{x})$, the individual will have to choose between:

- in case of migration a utility of $0.5 . \mathrm{L}_{\mathrm{n}}(100)+0.5 . \mathrm{L}_{\mathrm{n}}(20)+\beta .\left[0.8 . \mathrm{L}_{\mathrm{n}}(100)+0.2 . \mathrm{L}_{\mathrm{n}}\right.$ $(20)]=3.80+4.28 . \beta$

- in case of no-migration: $0.5 . \mathrm{L}_{\mathrm{n}}(60)+0.5 . \mathrm{L}_{\mathrm{n}}(240)+\beta .\left[0.5 . \mathrm{L}_{\mathrm{n}}(60)+0.2 . \mathrm{L}_{\mathrm{n}}(40)\right]=$ $3.89+3.89 . \beta$ 
So that the individual will migrate if and only if $\beta>0.23$, that is, if he does not discount « too much » future utilities.

Another aspect of the relation between migration and risk is that migration is not necessarily an individual decision, but rather a decision that involves a larger entity like family. The migration of one of its member can be a risk-diversification strategy for a family entity. As a matter of fact, agricultural activity is, by nature, dependent of climatic conditions and so it is risky. If the farmers are not allowed to insure themselves against climatic risk, and if they are risk-adverse, a possible strategy to diversify risk is to send to the city some of the individuals that compose the family. That will bring to the family a new source of income, not correlated with the original agricultural activity. Another possibility is to send people abroad, for example in a more developed country (as United States for a Mexican household, or European Union for a South-Mediterranean family). So, migration of some individuals to a city or to another country, followed by remittances sent home by the migrants, will permit a diversification of the risk incurred by the family entity.

\section{2-22: policy recommendations}

If migration is related to risk management, control of migration needs a reflexion about the factors which affect the activity in the sectors or the countries which send migrants. So, a better access to insurance could be a substitute to migration. As a matter of fact, migration has a high cost -both financial and emotional- for the family who send people to another sector or another country. Migration has also, eventually, a certain cost for the sector or the economy which receives migrants. So it seems possible to improve the situation by offering financial instruments (insurance contracts) to families which need to diminish their exposition to risk. One possibility could be to develop micro-insurance contracts more adapted to the needs of little farmers of developing countries, so that it would not be necessary for them to diversify the sources of income of the family by migrating and receiving remittances.

\section{2-3: Relative privation hypothesis}

\section{2-31: analysis}

Stark and Yitzhaki (1988), Stark (1991) and Stark and Taylor (1991) note that individuals do not migrate uniquely in response to "absolute income" consideration but also in response to "relative deprivation" or "relative income" considerations. That means that an individual is not only looking for improving his absolute income, but also he is willing to improve his relative situation in a "reference group". The "reference group" is originally the sending sector, i.e. the village, or the neighborhood, where migrants have their origin. As a matter of fact, migration can be a manner to make better the relative position of the family or the household in the origin group, by sending some of its members to a city or a Northern country. It is not even necessary to consider the family or the household as the decisional unit to make use of the concept of relative deprivation in economics of migration. An individual who migrates can still consider his village of origin as his "reference group", because he can for example be considered by the other members of his village as someone "who succeed" and he can demonstrate his relative success by sending remittances or by spending money when he returns home. A problem can emerge if the "reference group" changes when the 
migrants are better integrated in the receiving sector, but this problem is likely to appear only after a long period of time, and it will not appear at all in the case of seasonal migrants who come and go between the sector of origin and the place of temporary immigration. It is relevant to distinguish two issues in this approach: the problem of the measurement of relative deprivation, and the problem of the change of reference group.

First, let us consider the issue of how to measure relative deprivation. The idea is that we need at least two kinds of indicators, "numeric" indicators, which will measure for example the number of persons richer than I, and "volumetric" indicators, which will measure how much I am relatively deprived. Of course, a good synthetic indicator will depend at the same time of the first magnitude (the percentage of the population whose income is greater than mine) and the second one (average gap between the income of people richer than I and my own revenue). In consequence, we can use as an indicator of relative deprivation an indicator like PR:

$P R(y)=\{1-F(y)\} \cdot\{E(z-y \mid z>y)\}$

Where $\mathrm{F}(\mathrm{y})$ is the cumulative distribution function of income, and consequently $1-\mathrm{F}(\mathrm{y})$ is the percentage of individuals who have an income superior to $y$, and $E(z-y \mid z>y)$ is the expected value of the difference (z-y) for the revenues z superior to $y$. PR(y), the relative deprivation of an individual having an income $y$, is thus equal to the product of a numeric indicator by a volumetric indicator. To illustrate that, let us take the example of Stark and Taylor (1991):

We have an economy composed by a city and a village. Each inhabitant of the village at time $t$ has an income of 100, while each city dweller has an income of 200. If we suppose that for inhabitants of the village, reference group is the village, relative deprivation will be nil for them and so they will not migrate, in spite of the difference of income between the village and the city. Now we suppose that at time $t+1$ one half of the inhabitants have a raise of their income which becomes 150. Relative deprivation of the inhabitants whose income stays equal to 100 is $1 / 2$. $(150-100)=25$. One possibility for these households relatively deprived will be to send half of each household to the city, so that these households will reach an average income of $1 / 2 .(100+200)=150$. Migration will then make relative deprivation equal to zero. The interesting point is that the average gap between city and village is smaller at $t+1$ than it was at $\mathrm{t}$, but migration has begun only at $\mathrm{t}+1$.

We turn now to the problem of the "reference group". After a while, migrants may stop referring themselves to their village of origin and adopt the environment where they live as their new reference group. Obviously, this change is more likely to happen when migration is permanent and not transient (for example seasonal), and it will take a certain time after the migrant has established himself in his new environment. But it is also probable that change of reference group will be easier and faster when receiving sector is culturally close to sending sector. Stark (1991) and Stark and Taylor (1991) think that cultural and social differences make difficult a change of reference group in the case of international migrants. International migrants will then continue referring themselves to their group of origin, at least until their integration to the receiving country is complete. That will take a lot of time, and that will be longer when migrants of a same origin stay together in their receiving country, which is often the case.

The change of reference group is more frequent in the case of internal (rural-urban) migration, because in this case cultural differences are minimal. In this case, "return migration" will be 
more frequent, because after they change their reference group, individuals may experiment a relative deprivation more important in the city than the deprivation they used to have in their village of origin. Return migration will then occur as a strategy to diminish relative deprivation, even if it implies a decrease in absolute income. In a lot of cases the returning migrant has, when he returns, a better relative position than before his initial migration, because he has constituted a patrimony while he was working far from home.

\section{2-32: policy recommendations}

Relative deprivation hypothesis implies that inequality in distribution of income is also an important explanation for migration. If the individuals are sensitive not only to their absolute revenue but also to the difference between what they have and what the others possess, the important point is not so much the difference of income between the sending sector and the receiving sector, but rather the inequality in the distribution of income inside the reference group. So, in order to control migratory flows, it may be important to control the level of inequality in the potentially sending sectors, for example the Southern Countries if we consider international migration. If one believes in the Kuznets hypothesis of an inverted U curve between GDP per capita and inequality, it is possible to deduce from relative deprivation hypothesis that middle income countries (more unequal) are more likely to send migrants than low income countries.

\section{2-4: The role of Social Capital}

\section{2-41: Analysis}

Social capital "refers to the norms and networks that enable collective action" (website of the World Bank) and "is generally referred to as the set of trust, institutions, social norms, social networks, and organizations that shape the interactions of actors within a society and are an asset for the individual and collective production of well-being" (Fabio Sabatini's definition at www.socialcapitalgateway.org). In the 80's, French sociologist Pierre Bourdieu has defined social capital as "the set of actual or potential resources that are associated with the possession of a durable network of relationships (...) or, in other terms, with the membership of a group" (Bourdieu, 1980, p. 2). Other definition is Schiff's who defines social capital as "the set of elements of the social structure that affect relations among people and are inputs or arguments of the utility and/or production function" (Schiff, 2002, p. 88). It is easily understandable that migrations are linked to social capital. As a matter of fact, social capital can be theorized by the capacity of the individuals to cooperate, as it is developed in various articles which use the formalism of theory of repeated games (see Annen, 2003, DaytonJohnson, 2003, or Routledge and Von Amsberg, 2003, among others). Migrations can negatively affects social capital by diminishing incitation to cooperate: why should I cooperate today if I am going to migrate tomorrow and if I will never meet again the people I am playing with today? If one has to play again with the same players as today, and if 
individuals are punished in the future when they choose an aggressive strategy, "Folk Theorem" tell us that players (if they don't have a too high preference for present) will choose to cooperate in equilibrium. But if agents are continually changing of location, and thus if they have a very low probability to meet again in the future, this result is not valid anymore. This idea is summarized by E. Miguel who writes in his commentary of the article by Routledge and von Amsberg (2003): "Trust and Social Capital are undermined by extensive labour mobility, as individuals are no longer able to engage in the long term reciprocal relationships that nurture community cooperation" (p. 196). That creates a problem because "while social capital is critical in promoting economic growth, growth may destroy social capital" (ibid., p. 196), insofar as "growing societies periodically experience large technological shocks that generate pressure for labour mobility" (ibid, p. 195).

So, a first kind of problem is the influence of labour migration on social capital, which has been studied by Maurice Schiff in various articles (see Schiff, 1999 a, 1999 b and 2002). Schiff note that migration is considered as a major issue by most governments, but economic theory often considers free trade and free migration as equivalent. If free trade is desirable, why free migration shouldn't be desirable as well? How can we explain this difference? The point made by Schiff is that free migration is different from free trade because migrations affect social capital. The effect of migration on social capital appears in both the countries of emigration and immigration. In the sending country, social capital decreases with the level of migration "because of the reduction in the size of the group of people of similar background and values with whom each member of the group can interact" (Schiff, 2002, p. 92), which means in other words that "emigration results in a social capital drain" (ibid.). In the receiving country, social capital depends also negatively on migration, because migration affects the capacity of the members of society to share the same values and/or to communicate. If social capital is the ability and willingness of the members of society to act together for a common goal, the existence of a migrant population beside the native group can have two negative effects: the first effect alters the ability to act in common, because, for example, migrants may speak another language than natives and the second effect is related to the willingness to act in common, because the two populations may have different values, for example a different religion.

A second kind of problem has been studied by Massey (see Massey et alii, 1987, or Massey, 1999) and Zabin et alii (1993) and is related with the influence of social capital, or social networks, on migrations. We know that "migrants' networks", i.e. existence in an immigration sector (e.g. a Northern country, or a big city in a developing country) of an important community proceeding from a precise origin (for example a region, or a village), allied with a structure of relationships ("social capital") which links all the migrants the one with another and with the persons who are still in the sector of origin, fosters migration and shapes it in a specific way. So, economic determinants are not the only ones in motion when migrants are determining the destination they are going to take. The orientations of the flows of migrants are also dependent of the social networks already existing in the potential receiving sectors. Douglas Massey (1999) describes this phenomenon in these terms: "However an immigration stream begins, it displays a strong tendency to continue because of the growth and elaboration of migrants' networks (social capital theory). The concentration of immigrants in certain destination areas creates a "family and friends" effect that channels later streams of immigrants to the same places and facilitates their arrival and integration." (p. 306). Numerous examples can be made of that phenomenon, as the Mexican migration to the United States, or Chinese migrants' networks around the world. 
2-42: policy recommendations

We can deduce of the precedent theories two kinds of policy recommendations. On one hand, migration is not only an economic phenomenon, and so, it is not equivalent to free trade of goods or to free movements of capital. When people change of location, it destroys social networks formerly existing in the sending places and it affects social capital in the receiving sectors. So, migration must be managed cautiously. On the other hand, when networks of migrants have been established, migration is likely to continue even if initial incitation to migrate has disappeared. Thus, it is not necessarily sufficient to make economic incitation disappear to stop the migratory phenomenon. 


\section{3 - Synthesis}

We can summarize the main results of section 1 and 2 in the following table:

Table 3: Summary of the findings

\begin{tabular}{|c|c|c|}
\hline Model & Characteristics of the model & Main policy recommendations \\
\hline $\begin{array}{l}\text { Our Harris- } \\
\text { Todaro-Fields } \\
\text { type model } \\
\text { (section } 1)\end{array}$ & $\begin{array}{l}\text { Individuals migrate in response to a } \\
\text { difference in the expected income } \\
\text { between sectors. We study the no- } \\
\text { migration equilibrium. The model is } \\
\text { an exercise of comparative static, } \\
\text { comparing the equilibrium after an } \\
\text { initial change which is liberalization } \\
\text { of agriculture }\end{array}$ & $\begin{array}{l}\text { When the part of agricultural products in } \\
\text { total expenditure is low, liberalization may } \\
\text { provoke an increase in migration, in the } \\
\text { number of people employed in the informal } \\
\text { sector, and a decrease in agricultural salary. } \\
\text { So it will be difficult to have at the same time } \\
\text { control on migration, decrease of informality, } \\
\text { liberalization of trade and political stability. } \\
\text { When the part of agricultural products is high } \\
\text { the compatibility of these objectives is } \\
\text { greater but the budgetary equilibrium } \\
\text { objective is still difficult to attain at the same } \\
\text { time as the objectives previously mentioned. }\end{array}$ \\
\hline $\begin{array}{l}\text { Cost of } \\
\text { Migration } \\
\text { (section 2-1) }\end{array}$ & $\begin{array}{l}\text { The models in this tradition take } \\
\text { into account the fact that migration } \\
\text { is not free and that it generates } \\
\text { costs, both financial and emotional. } \\
\text { The financial cost is easier to } \\
\text { assume when sending country gets } \\
\text { richer }\end{array}$ & $\begin{array}{l}\text { When cost of migration is taken into account, } \\
\text { we will frequently have complementarity } \\
\text { between migration and trade, and so } \\
\text { liberalization will lead to an permanent } \\
\text { increase in the stock of migrants in the North. }\end{array}$ \\
\hline $\begin{array}{l}\text { Risk } \\
\text { management } \\
\text { (section 2-2) }\end{array}$ & $\begin{array}{l}\text { Migration can be a strategy of risk } \\
\text { avoidance and not of risk taking. } \\
\text { This can be explained by } \\
\text { considering that in the long run the } \\
\text { revenue in the city is less risky than } \\
\text { in the rural activity, or by supposing } \\
\text { that migration is the strategy of a } \\
\text { family which has a diversification } \\
\text { strategy by sending some of its } \\
\text { member to the city. }\end{array}$ & $\begin{array}{l}\text { Migration can be a form of insurance for a } \\
\text { family entity. As a matter of fact, by sending } \\
\text { some of its members abroad, the family is } \\
\text { diversifying its sources of revenue and so it } \\
\text { diminishes its risk. In order to control } \\
\text { migration, we could propose to families } \\
\text { micro-insurance contracts that fit better their } \\
\text { needs and are less costly than migration. }\end{array}$ \\
\hline $\begin{array}{l}\text { Relative } \\
\text { Deprivation } \\
\text { (section 2-3) }\end{array}$ & $\begin{array}{l}\text { Migration can be a response not to a } \\
\text { low absolute income but to a low } \\
\text { relative income. }\end{array}$ & $\begin{array}{l}\text { If individuals are sensitive not only to their } \\
\text { absolute income but also to the difference } \\
\text { between what they have and what the others } \\
\text { possess, the important point is not so much } \\
\text { the difference of income between the sending } \\
\text { sector and the receiving sector, but rather the } \\
\text { inequality in the distribution of income inside } \\
\text { the reference group. So, in order to control } \\
\text { migratory flows, it may be important to } \\
\text { control the level of inequality in the } \\
\text { potentially sending sectors }\end{array}$ \\
\hline
\end{tabular}




\begin{tabular}{|l|l|l|}
\hline $\begin{array}{l}\text { Social Capital } \\
\text { and networks } \\
\text { (section 2-4) }\end{array}$ & $\begin{array}{l}\text { Social capital, i.e. networks, can } \\
\text { have an influence on migration, and } \\
\text { reciprocally migration can influence } \\
\text { social capital. }\end{array}$ & $\begin{array}{l}\text { First, migration is not only an economic } \\
\text { phenomenon, and so, it is not equivalent to } \\
\text { free trade of goods or free movements of } \\
\text { capital. When people change of location, it } \\
\text { destroys social networks formerly existing in } \\
\text { the sending places and it affects social capital } \\
\text { in the receiving sectors. So, migration must } \\
\text { be managed cautiously. Secondly, when } \\
\text { networks of migrants have been established, } \\
\text { migration is likely to continue even if initial } \\
\text { incitation to migrate has disappeared. Thus, it } \\
\text { is not necessarily sufficient to make } \\
\text { economic incitation disappear to stop the } \\
\text { migratory phenomenon. }\end{array}$ \\
\hline
\end{tabular}




\section{BIBLIOGRAPHY}

Abed G.T. (1998), « Trade liberalization and tax reform in the Southern Mediterranean Region », IMF Working Paper, n $98 / 49$.

Annen K. (2003), Social Capital, inclusive networks, and economic performance, Journal of Economic Behavior and Organization, vol. 50, 449-463.

Bourdieu, P. (1980), "Le Capital Social, notes provisoires", Actes de la Recherche en Sciences Sociales, pp 2-3.

Dayton-Johnson J. (2003), Knitted warmth: the simple analytics of social cohesion, The journal of Socio-Economics, 32.

Ebrill L., J.G. Stotsky \& R. Gropp (1999), « Revenue implications of trade liberalization », I.M.F. Occasional Paper, $\mathrm{n}^{\circ} 180$.

Fields G. (1975), « Rural-urban migration, urban unemployment and underemployment and job search activity in LDC's », Journal of Development Economics, vol. 2, pp.165-187.

Grunberg I. (1998), « Double jeopardy: globalization, liberalization and the fiscal squeeze », World Development, vol.26, n4, pp.591-605.

Harris J.R. \& Todaro M.P. (1970), « Migration, unemployment and development: a two sector analysis », American Economic Review, vol.60, pp.126-142

Harrison A. \& G. Hanson (1999), « Who gains from trade reform? Some remaining puzzles », Journal of Development Economics, vol.59, pp.125-154.

Massey, D., R. Alarcon, J. Durand, H. Gonzalez (1987): Return to Aztlan: The Social Process of International Migration from Western Mexico, Berkeley, University of California Press.

Massey, D. (1999): «International Migration at the Dawn of the Twenty-First Century: The Role of the State», Population and Development Review, 25 (2), pp 303-322, June.

Miguel E. (2003), Comment on: Social Capital and Growth, Journal of Monetary Economics, 50, 195-198. 
Mundell, R. (1957): "International Trade and Factor Mobility", American Economic Review, $47,321-335$

Routledge B.R. and von Amsberg J. (2003), Social Capital and Growth, Journal of Monetary Economics, 50, 167-193.

Schiff, M. (1994), «How Trade, Aid, and Remittances Affect International Migration», Policy Research Working Paper WPS 1376, The World Bank.

Schiff, M. (1996), « South-North Migration and Trade. A Survey », Policy Research Working Paper WPS 1696, The World Bank.

Schiff, M. (1999 a): «Trade, Migration and Welfare: The impact of social capital », Policy Research Working Paper WPS 2044, The World Bank.

Schiff, M. (1999 b): «Labor market integration in the presence of social capital », Policy Research Working Paper WPS 2222, The World Bank.

Schiff (2002): «Love thy neighbor: trade, migration, and social capital », European Journal of Political Economy, vol. 18, pp 87-107.

Stark, O \& S. Yitzhaki (1988): «Migration as a response to relative deprivation », Journal of Population Economics, 1. Reprinted in Stark (1991).

Stark, O. (1991), The Migration of Labour, Blackwell Ed.

Stark, O. \& J. Edward Taylor (1991): « Relative Deprivation and Migration », Policy Research Working Paper WPS 656, The World Bank.

Stark, O. (1995): «Frontiers Issues in International Migration », Proceedings of the World Bank Annual Conference on Development Economics 1994, The World Bank.

Zabin C., M. Kearney, A. Garcia, D. Runsten, C. Nagengast (1993), Mixtec Migrants in California Agriculture, California Institute for Rural Studies, May. 
ANNEX: Value of Alpha in 66 Countries (other European countries, as well as North American countries, Japan, Australia or New Zealand, have value of alpha below 20\%). Calculated by USDA-ERS, using 1996 data.

\begin{tabular}{|c|c|c|c|}
\hline Country & $\begin{array}{c}\text { Total Food } \\
\text { Expenditure (\% total } \\
\text { expenditures) }\end{array}$ & Country & $\begin{array}{c}\text { Total Food } \\
\text { Expenditure (\% total } \\
\text { expenditures) }\end{array}$ \\
\hline Nigeria & 72,97 & Bahamas & 35,73 \\
\hline Albania & 69,26 & Jamaica & 34,78 \\
\hline Madagascar & 65,88 & Macedonia & 34,73 \\
\hline Vietnam & 64,75 & Russia & 34,35 \\
\hline Sri Lanka & 63,55 & Estonia & 33,45 \\
\hline Sierra Leone & 62,09 & Botswana & 32,80 \\
\hline Yemen & 61,13 & Argentina & 32,79 \\
\hline Bangladesh & 56,05 & Turkey & 32,60 \\
\hline Benin & 55,40 & Iran & 32,55 \\
\hline Malawi & 53,35 & Slovakia & 32,06 \\
\hline Senegal & 53,35 & Korea & 31,64 \\
\hline Mali & 53,27 & Belize & 31,17 \\
\hline Indonesia & 50,62 & Bulgaria & 30,70 \\
\hline Philippines & 48,35 & Poland & 30,65 \\
\hline Egypt & 48,08 & Peru & 30,31 \\
\hline Gabon & 47,94 & Venezuela & 29,47 \\
\hline Syria & 47,92 & Ecuador & 29,09 \\
\hline Pakistan & 46,99 & Thailand & 28,56 \\
\hline Congo & 46,92 & Bahrain & 28,55 \\
\hline Kenya & 45,82 & Mauritius & 28,12 \\
\hline Morocco & 45,61 & Swaziland & 27,48 \\
\hline Romania & 45,26 & Paraguay & 27,27 \\
\hline Ukraine & 45,03 & Mexico & 26,63 \\
\hline Cote d'Ivoire & 44,32 & Qatar & 26,22 \\
\hline Cameroon & 43,80 & Zimbabwe & 25,58 \\
\hline Guinea & 43,69 & Uruguay & 25,25 \\
\hline Moldova & 43,45 & Czech Republic & 25,00 \\
\hline Bolivia & 42,52 & Portugal & 23,23 \\
\hline Lithuania & 40,42 & Chile & 22,96 \\
\hline Lebanon & 39,33 & Brazil & 22,71 \\
\hline Dominica & 38,27 & Hungary & 22,54 \\
\hline Jordan & 37,67 & Slovenia & 21,34 \\
\hline Tunisia & 35,95 & Greece & 21.17 \\
\hline
\end{tabular}

Source: US Department of Agriculture, Economic Research Service

(http://www.ers.usda.gov/data/InternationalFoodDemand) 